\title{
The cost of health services at the facilities level of the Nakuru Municipal Council, Nakuru, Kenya
}

Andrew Thompson

Barbara Janowitz

Julie Solo

Follow this and additional works at: https://knowledgecommons.popcouncil.org/departments_sbsr-rh

Part of the Demography, Population, and Ecology Commons, Family, Life Course, and Society Commons, and the International Public Health Commons How does access to this work benefit you? Let us know!

\section{Recommended Citation}

Thompson, Andrew, Barbara Janowitz, and Julie Solo. 1999. "The cost of health services at the facilities level of the Nakuru Municipal Council, Nakuru, Kenya," Africa OR/TA Project II. Nairobi: Population Council. 

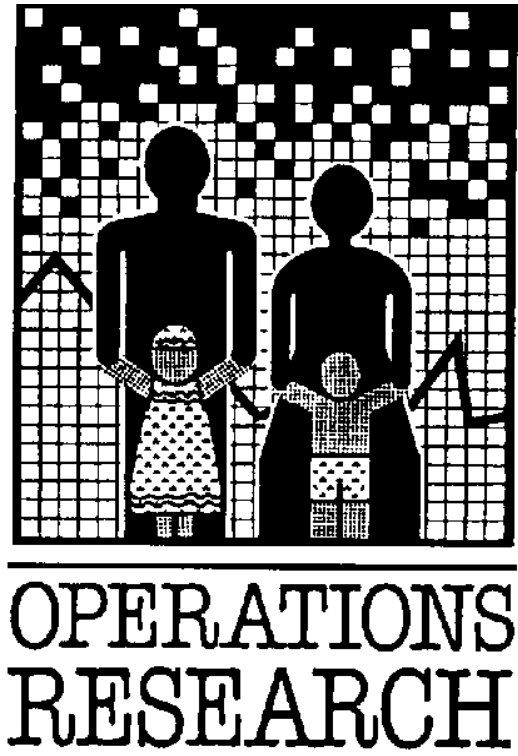

TECHNICAL ASSISTANCE

AFRICA PROJECT II

THE POPULATION COUNCIL

\section{The Cost of Health Services at the Facilities Level of the Nakuru Municipal Council, Nakuru, Kenya}

Family Health International

Julie Solo

Africa OR/TA Project II The Population Council 


\section{The Population Council}

The Population Council seeks to help improve the wellbeing and reproductive health of current and future generations around the world and to help achieve a humane, equitable, and sustainable balance between people and resources. The Council analyzes population issues and trends; conducts biomedical research to develop new contraceptives; works with public and private agencies to improve the quality and outreach of family planning and reproductive health services; helps governments to influence demographic behavior; communicates the results of research in the population field to appropriate audiences; and helps build research capacities in developing countries. The Council, a nonprofit, non governmental research organization established in 1952, has a multinational Board of Trustees; its New York headquarters supports a global network of regional and country offices.

This project was supported by the Population Council's Operations Research and Technical Assistance Project II, Project No. 936-3030, and by the Population Council's Cooperative Agreement with No. CCP3050-A-00-4013-00, both funded by the United States Agency for International Development (USAID). 


\section{TABLE OF CONTENTS}

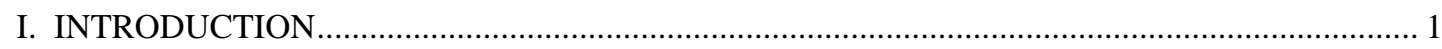

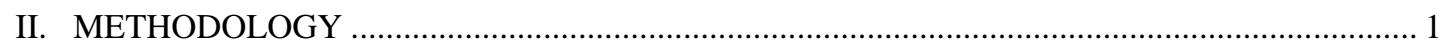

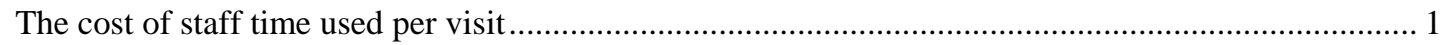

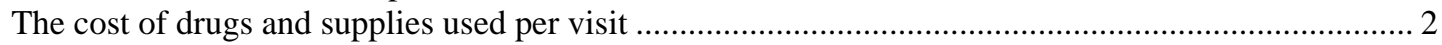

The pro-rated share of general clinic expenses................................................................................. 3

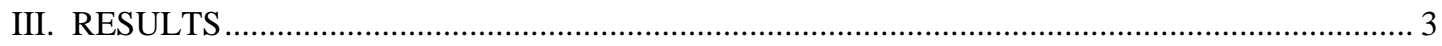

Visits by type and clinic .............................................................................................................. 3

The amount of clinic resources used to produce different types of visits ................................................. 3

Total contact time for different types of visits ................................................................................ 3

Average Visits per Day............................................................................................................. 5

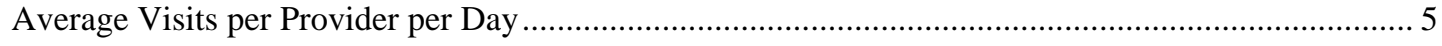

Cost per minute of provider time .............................................................................................. 5

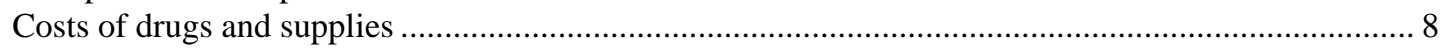

Average cost per visit ....................................................................................................... 9

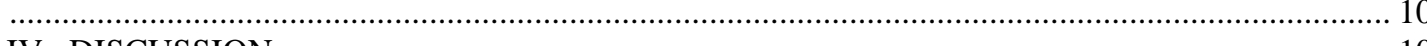

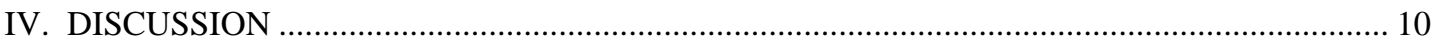




\section{INTRODUCTION}

The Nakuru Municipal Council (NMC) is concerned with the financial sustainability of its services, and thus is considering increasing its prices. They are currently charging for services but these fees are not based upon the cost of providing services. Before changing its prices, the NMC therefore wanted information on its costs. Another strategy to increase financial sustainability is to decrease costs of producing various services. Information on current costs of its various services can also help the NMC to determine ways to reduce these costs.

To address these issues, the NMC, in collaboration with the Africa OR/TA II project and Family Health International (FHI), conducted a study to measure the recurrent financial costs of providing visits for different types of services. We included Family Planning (FP), Sexually Transmitted Infections (STI) management, antenatal care, child health, tuberculosis (TB) and outpatient treatment. The cost analysis focused on recurrent costs, or the costs of inputs that are consumed within one year. Since the primary reason for conducting the study was to provide information to help set prices, we decided not to include capital costs as we were certain that it would be difficult to cover even recurrent costs. Recurrent costs include resources that vary with the number of visits, such as drugs and supplies, as well as resources that are unlikely to change with the number of visits, such as labor and overhead (water, telephone, cleaning materials, etc.). The cost of capital inputs, such as the building and equipment, were not included.

\section{METHODOLOGY}

In this analysis, the cost of producing a visit equals the sum of the costs of staff time, drugs and supplies and the pro-rated share of general clinic expenses. This section describes how each of these costs was calculated.

\section{The cost of staff time used per visit}

The cost of staff time used per visit equals the sum of the labor costs for each clinic worker who had contact with the client. The cost per visit for each clinic worker was calculated by using the following formula:

\begin{tabular}{|c|c|c|}
\hline $\begin{array}{l}\text { Average number of minutes } \\
\text { in contact with a client for }\end{array}$ & $X$ & $\begin{array}{l}\text { Labor cost of one minute } \\
\text { of contact time }\end{array}$ \\
\hline
\end{tabular}

Patient flow analysis (PFA) was used to determine the average number of minutes spent by providers on each type of visit. PFA measures the flow of clients through the clinic, including the amount of time that clinic workers spend with clients during each type of visit. Each client receives a PFA form upon entering the clinic and keeps it with her throughout the course of the visit. During consultations with the client, clinic staff note the beginning and end times of the contact on the PFA form. The purpose of the visit is determined by reviewing the client's record. By adding the time that each of the providers spends with a client, the total time that a client spends 
in contact with providers may be determined. However, it should be noted that this figure is less than the total time spent in the clinic as clients spend some time waiting to consult with the next provider.

The PFA was conducted all day long for those days that the clinic was open (Monday to Frideay) in each of the five NMC clinics: Bondeni, Industrial Area, Nakuru West, Lanet and Langa Langa. Two PFA coordinators in each clinic were responsible for monitoring data collection and for identifying the purpose of each visit.

The cost of one minute of the time of a particular staff member used to provide a visit was determined as follows:

Annual Salary plus benefits

Number of expected days of work per year $x$ Number of minutes per day spent with clients

Information was obtained from the NMC administration on the salaries and benefits paid to clinic staff. For each worker, the expected number of days worked per year was estimated by adjusting a yearly calendar to subtract the number of weekends, holidays, annual leave days, and other leave days. The average number of minutes spent by a provider per day with clients was obtained by adding all contact minutes recorded in the PFA.

\section{The cost of drugs and supplies used per visit}

The cost of drugs and supplies used per visit was calculated as follows:

\section{Number of units of each item used per visit $\quad x \quad$ Unit cost of each item}

Information was obtained from a sample of providers on the type and amount of drugs, gloves and other supplies used during different types of visits. We excluded items that were used more than once such as speculums. In addition, we excluded some items for which the cost per visit would be very low such as disinfectant. The unit cost of each item was obtained from the NMC Purchasing Office. We excluded donated items as the NMC was not interested in including costs of supplies that were borne by other organizations, but only its own financial outlays. Therefore, donated items, such as contraceptives, tuberculosis treatment, and polio vaccines were not included in the analysis.1

1 Major donors of these items include the MOH, USAID, DfID, CIDA, and GTZ. 


\section{The pro-rated share of general clinic expenses}

We assumed that each visit uses an equal amount of clinic expenses. Therefore, we divided the average monthly expenditure by the average number of visits per month.

Information on clinic expenses was obtained from the NMC's 1996/97 Expenditure Estimates Report. Estimates include subsistence allowances, uniforms, operations (minus medical supplies, drugs and dressings), public health communication, and maintenance. The PFA also provided information on the average number of visits per month as the data from the NMC were not organized so as to provide this information.

\section{RESULTS}

\section{Visits by type and clinic}

Table 1 shows the percentage distribution of visits in the NMC according to type and clinic. The most common visits in each clinic are for outpatient treatment, and for the combined group of antenatal and child health services. Among the clinics, Langa Langa and Lanet account for 70 percent of all visits.

Table 1. Percentage Distribution of Visits According to Type and Clinic

$$
(\mathrm{N}=2,185)
$$

\begin{tabular}{lcccccc}
\multicolumn{1}{c}{ Service } & Bondeni & $\begin{array}{c}\text { Industrial } \\
\text { Area }\end{array}$ & $\begin{array}{c}\text { Nakuru } \\
\text { West }\end{array}$ & Lanet & $\begin{array}{c}\text { Langa } \\
\text { Langa }\end{array}$ & Total \\
\hline FP & 0 & 0 & 1 & 2 & 3 & $\mathbf{6 \%}$ \\
Antenatal & 2 & 1 & 3 & 4 & 7 & $\mathbf{1 6 \%}$ \\
Child Health & 2 & 1 & 2 & 5 & 7 & $\mathbf{1 7 \%}$ \\
Outpatient & 4 & 2 & 5 & 14 & 15 & $\mathbf{4 0 \%}$ \\
Tuberculosis & 2 & 0 & 3 & 1 & 6 & $\mathbf{1 3 \%}$ \\
STI & 0 & 0 & 0 & 1 & 1 & $\mathbf{2 \%}$ \\
Other & 0 & 0 & 0 & 0 & 5 & $\mathbf{5 \%}$ \\
Total & $\mathbf{1 1 \%}$ & $\mathbf{4 \%}$ & $\mathbf{1 4 \%}$ & $\mathbf{2 6 \%}$ & $\mathbf{4 4 \%}$ & $\mathbf{1 0 0 \%}$
\end{tabular}

\section{The amount of clinic resources used to produce different types of visits}

\section{Total contact time for different types of visits}

Table 2 shows the number of minutes and the percentage of the day that staff members of each type spend with clients. Only clinic officers, nurses and ungraded nurses are shown, as these employees are the primary service providers. Clinic officers (COs) are the busiest providers in terms of time spent with clients; they spend almost one quarter of the workday with clients. The relatively large amount of time spent by COs with clients may be explained by the fact that there is only one CO per clinic and he typically attends almost all the outpatient clients. Nurses spend the next highest percent of time with clients with this percent varying by a factor of about 
three. The ungraded nurses have the least contact with clients; however, the time spent with clients varies greatly. Ungraded nurses in Lanet and Langa Langa spend two to seven times as much time with clients as do ungraded nurses in the other clinics.

Table 2. Average Minutes per Day and Percentage of Workday Spent with Clients According to Type of Provider and Clinic

\begin{tabular}{|c|c|c|c|c|c|c|c|}
\hline & Bondeni & $\begin{array}{c}\text { Industrial } \\
\text { Area }\end{array}$ & $\begin{array}{l}\text { Nakuru } \\
\text { West }\end{array}$ & Lanet & $\begin{array}{l}\text { Langa } \\
\text { Langa }\end{array}$ & Average & $\begin{array}{l}\text { Percentage } \\
\text { Of } 8 \text { hour } \\
\text { Work Day }\end{array}$ \\
\hline Provider Type & & & & & & & \\
\hline Clinic Officer & 99 & 0 & 96 & 215 & 165 & 116 & $24 \%$ \\
\hline Nurse & 64 & 35 & 40 & 119 & 81 & 65 & $14 \%$ \\
\hline Origraueu ivurse & 8 & 11 & 24 & 62 & 52 & 29 & $6 \%$ \\
\hline $\begin{array}{l}\text { Percentage of } 8 \\
\text { hour work day of } \\
\text { above staff* }\end{array}$ & $8 \%$ & $4 \%$ & $8 \%$ & $23 \%$ & $16 \%$ & & $12 \%$ \\
\hline
\end{tabular}

* Includes all COs, nurses and ungraded nurses.

On average, providers spend 12 percent of an eight-hour workday with clients.

However, there is a great deal of variation. For example, providers in Lanet spend 23 percent of the day attending to clients while their counterparts in Industrial Area spend only four percent of the day with clients. Although we are unable to determine what providers do when they are not seeing clients, it is likely that some of the noncontact time is spent on essential tasks related to visits. Productive uses of time include such activities as preparing the workspace and cleaning up after a visit, or on carrying out administrative tasks such as completing client records and service statistics. However, it is unlikely that all time non-contact time is spent in this way. It is probable that some of the time is spent waiting to serve clients.

One factor that clearly affects how providers spend their time is the number of clients that they attend. Although the number of providers varies little among the clinics, there are great variations in the total number of visits. Table 3 shows that the average daily number of visits is highest in the two clinics in which the number of visits is highest and in which providers also spend the most time with clients (Table 2). 
Table 3. Average Number of Daily Visits per Provider by Clinic

\begin{tabular}{|c|c|c|c|c|c|c|}
\hline & Bondeni & $\begin{array}{l}\text { Industrial } \\
\text { Area }\end{array}$ & $\begin{array}{l}\text { Nakuru } \\
\text { West }\end{array}$ & Lanet & $\begin{array}{l}\text { Langa } \\
\text { Langa }\end{array}$ & Average \\
\hline Number of Providers* & 10 & 11 & 12 & 10 & 13 & 12 \\
\hline $\begin{array}{l}\text { Average Visits per Day } \\
\text { Average Visits per }\end{array}$ & 48 & 18 & 62 & 115 & 194 & 87 \\
\hline Provider per Day & 4.8 & 1.6 & 4.4 & 11.5 & 14.9 & 7.3 \\
\hline
\end{tabular}

* Including only COs, Nurses, and Ungraded Nurses

Table 4 shows the average time spent with providers in each clinic by type of visit. Contact time is longest for family planning and STIs (the length of contact time is determined by adding all contact segments with individual providers). While the average contact time is generally lowest in Langa Langa, which is one of the two busiest clinics, it is similar in Lanet to that of the other three clinics. Moreover, the percent of time that providers spend with clients is higher in Lanet than in Langa Langa. Therefore, it is unlikely that there is any association between total length of contact time and percent of provider time spent with clients. This finding is not surprising as the percent of time spent by providers with clients is low.

Table 4. Average Number of Minutes Spent with Providers by Type of Visit and Clinic

\begin{tabular}{|c|c|c|c|c|c|c|}
\hline \multirow{2}{*}{ Service } & \multicolumn{4}{|c|}{ Industrial Nakuru } & & $\begin{array}{c}\text { Clinic } \\
\text { Average }\end{array}$ \\
\hline & Bondeni & Area & West & Lanet & $\begin{array}{l}\text { Langa } \\
\text { Langa }\end{array}$ & \\
\hline FP* & $\mathrm{n} / \mathrm{a}$ & 29 & 20 & 20 & 12 & 17 \\
\hline Antenatal & 16 & 11 & 18 & 16 & 8 & 13 \\
\hline Child Health & 8 & 13 & 12 & 6 & 5 & 7 \\
\hline Outpatient & 12 & 11 & 12 & 10 & 7 & 9 \\
\hline Tuberculosis² & 2 & $n / a$ & 3 & 4 & 4 & 3 \\
\hline STI & 13 & 10 & 20 & 20 & 16 & 17 \\
\hline
\end{tabular}

$\mathrm{n} / \mathrm{a}=$ Service not available or not provided during data collection

* FP includes visits in which any type of contraceptive method or FP information was provided.

\section{Cost per minute of provider time}

Table 5 shows the calculations to determine the average labor cost per minute. The example of Langa Langa clinic is shown. First the total remuneration of each staff member is calculated, and includes the annual salary of the provider plus benefits. This figure is then adjusted so as to provide information on the cost of one minute of contact time. We calculate contact time of an average provider by determining the total number of days that the provider works per year (adjusting for holidays and leave) and then multiplying that number by the total time that the provider spends in contact with a client. For each type of personnel the following steps were followed:

2 TB visits are short because clients bypass standard clinic flow procedures and report directly to a nurse for immediate treatment. 
1. Total Annual Remuneration = Annual Salary x $(1+$ Social Security Contribution Percentage $)+$ Annual Benefits

2. Cost per Minute of Time $=$ Total Annual Remuneration/ (Number of Days at Work per Year $x$ Average Number of Minutes Spent with Clients per Day)

The average labor cost per minute of time spent with clients at Langa Langa clinic is 0.51 Kenyan pounds. This average was weighted according to the number of each type of clinic personnel.

Table 5. Calculation of Average Labor Cost per Minute of Time Spent with Clients at Langa Langa Clinic (In Kenyan Pounds*)

\begin{tabular}{lcccccccc}
\multicolumn{1}{c}{ Personnel } & $\begin{array}{c}\text { Average } \\
\text { Salary }\end{array}$ & NSSF** & $\begin{array}{c}\text { Average } \\
\text { Benefits }\end{array}$ & $\begin{array}{c}\text { Total } \\
\text { Remuneration }\end{array}$ & $\begin{array}{c}\text { Annual } \\
\text { Days } \\
\text { Worked\# }\end{array}$ & $\begin{array}{c}\text { Most per } \\
\text { Day }\end{array}$ & $\begin{array}{c}\text { Minutes per } \\
\text { Day with } \\
\text { Clients\# }\end{array}$ & $\begin{array}{c}\text { Cost per } \\
\text { Minute }\end{array}$ \\
\hline Clinic Officer & 8,259 & 1.12 & 1,980 & 11,230 & 213 & 53 & 165 & 0.32 \\
Nurse & 5,356 & 1.12 & 1,740 & 7,739 & 219 & 35 & 81 & 0.44 \\
Ungraded Nurse & 3,091 & 1.05 & 1,320 & 4,566 & 221 & 21 & 52 & 0.40 \\
Subordinate & 2,290 & 1.05 & 1,020 & 3,425 & 223 & 15 & 19 & 0.79 \\
Lab. Tech. & 6,176 & 1.12 & 1,770 & 8,687 & 219 & 40 & 25 & 1.59 \\
Average & $\mathbf{3 , 7 6 9}$ & $\mathbf{1 . 0 8}$ & $\mathbf{1 , 3 7 4}$ & $\mathbf{5 , 4 4 5}$ & $\mathbf{2 2 1}$ & $\mathbf{2 5}$ & $\mathbf{4 8}$ & $\mathbf{0 . 5 1}$
\end{tabular}

* 1 Kenyan Pound $=20$ Kenyan Shillings

** Nakuru Municipal Council's contributes a percentage of the staff member's salary to the National Social Security Fund. For example, $1.12=12 \%$.

\# Annual Days Worked equals 260 possible annual workdays minus annual leave and official holidays. Information on the number of sick days taken was not available and therefore not included in the calculation.

\# \#Minutes per Day with Clients is shown in Table 2.

Table 6 shows the labor cost by type of visit according to clinic. For each clinic the average contact time per service (Table 4 ) is multiplied by the average labor cost of one minute of contact time (Table 5). The table clearly shows that labor costs per visit vary greatly by clinic. Labor costs are lowest in Lanet and Langa Langa, reflecting the fact that providers spend the highest percentage of time with clients in those two clinics. Labor costs in the three other clinics are much higher.

It needs to be pointed out that the labor cost of a visit is made up of two components. One component is the cost of the time actually spent with a client. The second may be thought of as an "overhead" cost and is the allocated cost of the time not spent with clients but which must be assigned to visits. Since the number of minutes spent on a visit of a particular type varies little by clinic, the major reason for the difference in labor costs may be attributed to this "overhead" time. Thus the cost of any type of clinic visit is lower in Lanet and Langa Langa because the "overhead" component of labor cost per visit is lowest in these clinics. 
Table 6. Calculation of Labor Cost per Visit According to Clinic

(In Kenyan Pounds)

\begin{tabular}{|c|c|c|c|c|c|c|c|c|c|c|c|c|c|c|c|}
\hline \multirow[b]{2}{*}{ Visit } & \multicolumn{3}{|c|}{ Bondeni } & \multicolumn{3}{|c|}{ Industrial Area } & \multicolumn{3}{|c|}{ Nakuru West } & \multicolumn{3}{|c|}{ Lanet } & \multicolumn{3}{|c|}{ Langa Langa } \\
\hline & $\begin{array}{c}\text { Average } \\
\text { Visit } \\
\text { Length }\end{array}$ & $\begin{array}{c}\text { Labor } \\
\text { Cost } \\
\text { Per } \\
\text { Minute }\end{array}$ & $\begin{array}{c}\text { Labor } \\
\text { Cost } \\
\text { Per } \\
\text { Visit } \\
\end{array}$ & $\begin{array}{c}\text { Average } \\
\text { Visit } \\
\text { Length }\end{array}$ & $\begin{array}{c}\text { Labor } \\
\text { Cost } \\
\text { per } \\
\text { Minute }\end{array}$ & $\begin{array}{c}\text { Labor } \\
\text { Cost } \\
\text { per } \\
\text { Visit }\end{array}$ & $\begin{array}{c}\text { Average } \\
\text { Visit } \\
\text { Length }\end{array}$ & $\begin{array}{c}\text { Labor } \\
\text { Cost } \\
\text { per } \\
\text { Minute }\end{array}$ & $\begin{array}{c}\text { Labor } \\
\text { Cost } \\
\text { per } \\
\text { Visit }\end{array}$ & $\begin{array}{c}\text { Average } \\
\text { Visit } \\
\text { Length }\end{array}$ & $\begin{array}{c}\text { Labor } \\
\text { Cost } \\
\text { per } \\
\text { Minute }\end{array}$ & $\begin{array}{c}\text { Labor } \\
\text { Cost } \\
\text { per } \\
\text { Visit } \\
\end{array}$ & $\begin{array}{l}\text { Average } \\
\text { Visit } \\
\text { Length }\end{array}$ & $\begin{array}{l}\text { Labor } \\
\text { Cost } \\
\text { per } \\
\text { Minute }\end{array}$ & $\begin{array}{c}\text { Labor } \\
\text { Cost } \\
\text { per } \\
\text { Visit }\end{array}$ \\
\hline$P$ & $\mathrm{n} / \mathrm{a}$ & 0.73 & 0.00 & 29 & 1.67 & 48.33 & 20 & 0.72 & 14.46 & 20 & 0.30 & 5.93 & 12 & 0.51 & 6.17 \\
\hline ntena & & & & & & & & & & & & & & & 4.12 \\
\hline Child $\mathrm{r}$ & 8 & 0.73 & 5.81 & 13 & 1.67 & 21.66 & 12 & 0.72 & 8.6 & 6 & 0.30 & 1.78 & 5 & 0.51 & 2.57 \\
\hline utpa & 12 & 0.73 & 8.7 & 1 & 1.67 & 18.3 & 12 & 0.72 & 8.67 & 10 & 0.3 & 2. & 7 & & 3.60 \\
\hline Iube & 2 & & & $n / a$ & & & 3 & & & & & & 4 & & 2.06 \\
\hline STI & 13 & 0.73 & 9.43 & 10 & 1.67 & 16.67 & 20 & 0.72 & 14.46 & 20 & 0.30 & 5.93 & 16 & 0.51 & 8.23 \\
\hline
\end{tabular}




\section{Costs of drugs and supplies}

Table 7 shows the cost of drugs and supplies used in different types of visits. ${ }^{3}$ Supplies mainly include gloves, needles and syringes needed to support these visits plus the drugs provided in outpatient visits.

Table 7. Cost of Drugs and Supplies Used by Type of Visit

(In Kenyan Pounds)

\begin{tabular}{llccc} 
Service & \multicolumn{1}{c}{$\begin{array}{c}\text { Item } \\
\text { Used }\end{array}$} & $\begin{array}{c}\text { Amount Used } \\
\text { Per Visit }\end{array}$ & $\begin{array}{c}\text { Cost per } \\
\text { Unit }\end{array}$ & $\begin{array}{c}\text { Cost per } \\
\text { Visit }\end{array}$ \\
\hline FP new visit & Sterile gloves (pair) & 2 & 2.00 & $\mathbf{4 . 0 0}$ \\
Antenatal new & & & & \\
visit* & Sterile gloves (pair) & 1 & 2.00 & 2.00 \\
& RPR Test & 1 & 0.07 & 0.07 \\
& 300 ml needle/syringe & 1 & 0.25 & 0.25 \\
& Urinalysis kit & 1 & 0.63 & 0.63 \\
Child Health & Total & & & $\mathbf{2 . 9 5}$ \\
& BCG needle/syringe & 1 & 0.30 & 0.30 \\
& DPT needle/syringe & 1 & 0.25 & 0.25 \\
Outpatient & Total & & & $\mathbf{0 . 5 5}$ \\
& Various drugs** & & 1.00 & $\mathbf{1 . 0 0}$
\end{tabular}

* Antenatal clients make 3 follow-up visits during which drugs and supplies typically are not used.

** Various drugs are used to treat outpatient clients; the unit cost of an average dose is about 1 Kenyan pound.

\section{Cost of general clinic expenditures}

Table 8 shows the average cost of general clinic expenditures per visit. Lanet's cost per visit for these items is lowest at 0.40 Kenyan pounds per visit, while Industrial Area is highest at 3 Kenyan pounds, while the average was 0.95. Since these expenditures are fixed by clinic the cost per visit declines as the number of visits increases. Thus, a clinic with a large number of visits such as Lanet or Langa Langa will have lower expenditures per visit.

Table 8. Cost of General Clinic Expenditures per Visit by Clinic (In Kenyan Pounds)

\begin{tabular}{|c|c|c|c|c|c|c|}
\hline & Bondeni & $\begin{array}{c}\text { Industrial } \\
\text { Area }\end{array}$ & $\begin{array}{c}\text { Nakuru } \\
\text { West }\end{array}$ & Lanet & Langa Langa & $\begin{array}{l}\text { Clinic } \\
\text { Average }\end{array}$ \\
\hline Monthly Expenditures & 1,417 & 1,176 & 1,454 & 1,007 & 4,091 & 1,829 \\
\hline Visits per Month & 1,047 & 392 & 1,373 & 2,539 & 4,268 & 1,924 \\
\hline Cost per Visit & 1.35 & 3.00 & 1.06 & 0.40 & 0.96 & 0.95 \\
\hline
\end{tabular}

3 Donors provide the drugs used in child health, TB and STI visits as well as the contraceptives used in FP visits. Therefore, these costs were not included. 


\section{Average cost per visit}

Table 9 shows the components of the average cost of an outpatient visit in each clinic. Average cost per visit varies substantially with the lowest costs in the two busiest clinics. This result is not surprising as labor accounts for the highest percentage of costs ranging from 65 percent in Langa Langa to 82 percent in Industrial Area, and labor costs are lowest in the busiest clinics.

Table 9. Cost of an Outpatient Visit by Component According to Clinic (In Kenyan Pounds)

\begin{tabular}{lcccccc}
\multicolumn{1}{c}{ Type of Cost } & Bondeni & $\begin{array}{c}\text { Industrial } \\
\text { Area }\end{array}$ & $\begin{array}{c}\text { Nakuru } \\
\text { West }\end{array}$ & Lanet & $\begin{array}{c}\text { Clinic } \\
\text { Langa } \\
\text { Langa }\end{array}$ & \begin{tabular}{c} 
Average* \\
\hline Labor
\end{tabular} \\
Drugs and Supplies & 1.00 & 18.33 & 8.67 & 2.97 & 3.60 & 5.37 \\
Clinic Expenditures & 1.35 & 1.00 & 1.00 & 1.00 & 1.00 & 1.00 \\
$\quad$ Total & $\mathbf{1 1 . 0 6}$ & $\mathbf{2 2 . 3 3}$ & $\mathbf{1 0 . 7 3}$ & $\mathbf{4 . 3 7}$ & $\mathbf{5 . 5 6}$ & $\mathbf{7 . 3 2}$ \\
$\quad$ Total (US\$)** & $\mathbf{3 . 6 9}$ & $\mathbf{7 . 4 4}$ & $\mathbf{3 . 5 8}$ & $\mathbf{1 . 4 6}$ & $\mathbf{1 . 8 5}$ & $\mathbf{2 . 4 4}$
\end{tabular}

* Based on a weighted average of outpatient visits produced in each clinic

** 3 Kenyan Pounds $=1$ U.S. Dollar

Table 10 shows the average cost per visit by type of visit and by clinic. Not unexpectedly, visit costs are always lowest for Lanet and Langa Langa. Figure 1 shows the same information for outpatient visits.

Figure 1. Average Cost of Outpatient

Visits by Clinic

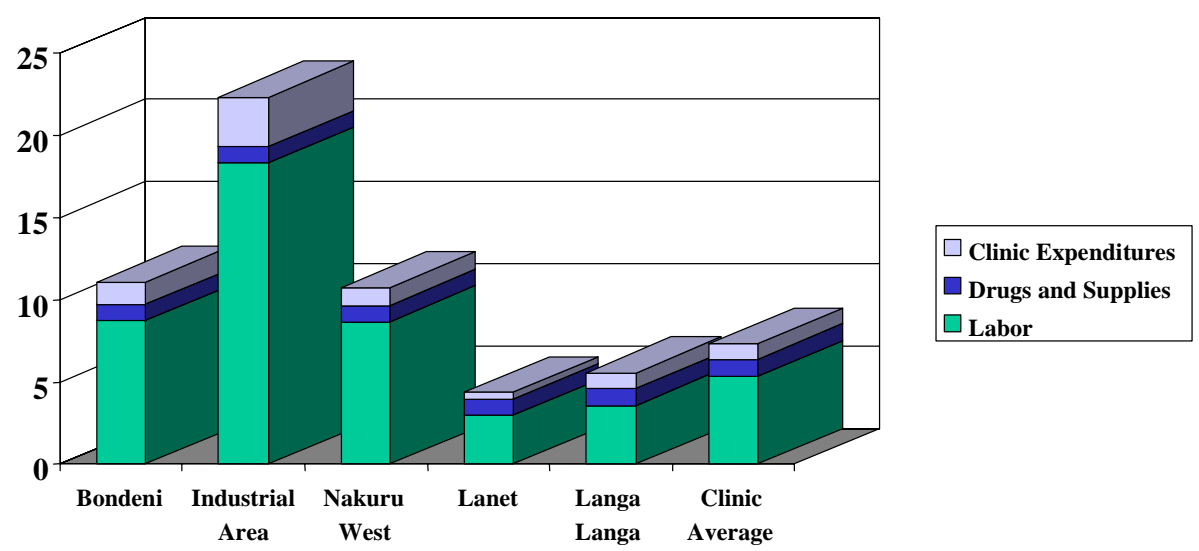


Table 10. Average Cost per Visit by Type of Visit and Clinic

(In Kenyan Pounds)

\begin{tabular}{lccccccc} 
Service & Bondeni & $\begin{array}{c}\text { Industrial } \\
\text { Area }\end{array}$ & $\begin{array}{c}\text { Nakuru } \\
\text { West }\end{array}$ & Lanet & $\begin{array}{c}\text { Langa } \\
\text { Langa }\end{array}$ & $\begin{array}{c}\text { Clinic } \\
\text { Average* }\end{array}$ & $\begin{array}{c}\text { Clinic } \\
\text { Average (US\$) }\end{array}$ \\
\hline FP & n/a & 51.33 & 15.52 & 6.33 & 7.13 & $\mathbf{1 0 . 7 5}$ & $\mathbf{3 . 5 8}$ \\
Antenatal & 13.70 & 22.07 & 14.81 & 5.89 & 5.82 & $\mathbf{9 . 1 0}$ & $\mathbf{3 . 0 3}$ \\
Child Health & 7.71 & 25.21 & 10.28 & 2.73 & 4.08 & $\mathbf{5 . 5 8}$ & $\mathbf{1 . 8 6}$ \\
Outpatient & 11.06 & 22.33 & 10.73 & 4.37 & 5.56 & $\mathbf{7 . 3 2}$ & $\mathbf{2 . 4 4}$ \\
Tuberculosis & 2.80 & $\mathrm{n} / \mathrm{a}$ & 3.23 & 1.59 & 3.02 & $\mathbf{2 . 8 0}$ & $\mathbf{0 . 9 3}$ \\
STI & 10.78 & 19.67 & 15.52 & 6.33 & 9.19 & $\mathbf{1 0 . 7 4}$ & $\mathbf{3 . 5 8}$
\end{tabular}

* Based on a weighted average of outpatient visits produced in each clinic $\mathrm{n} / \mathrm{a}=$ Service not available or not provided during data collection

\section{DISCUSSION}

Our findings show that the most important component of recurrent costs is labor. Thus, variations in the cost of labor are associated with variations in the cost of the services produced. In the busiest clinics in which a higher percentage of staff time is spent in direct contact with clients, the labor costs of services is lower. In a clinic with a very low volume of clients, such as Industrial Area, the cost of services is far higher because such a high percentage of staff time is unoccupied. Although PFA does not provide information on how providers spend their time when they are not with clients, we can be reasonably sure that some time not spent with clients is spent "waiting” because of low client volume.

Since costs per visit are high because client volume is low, these costs can be reduced either by increasing client load or by decreasing total recurrent costs. The NMC may wish to consider the possible options to either reduce costs or increase client volume. An increase in client volume would decrease "overhead" labor costs in that more time of staff would be spent with clients as less "overhead" time would need to be charged to visits. For example, the labor cost of a visit is higher in Industrial Area than in Lanet. This finding occurs because the "overhead" time that must be charged off to visits is so much higher in Industrial Area than in Lanet. Variations in the amount of time that providers spend with clients has very little impact on the cost of a visit. It is therefore apparent that if the client load in the Industrial Area clinic were to increase by a factor of five or more that its labor costs per visit would approximate those in Lanet.

While the most attractive scenario to accomplish this goal would be for the number of client visits to increase, it is not clear what steps, if any, clinics could take to increase the volume of clients. However, a first step would be to explore the reasons for the low client demand for services. A second alternative would be to reduce the number of staff at each clinic or to reduce the number of clinics. If client demand cannot be increased, then the NMC may be forced to consider this alternative.

One of the reasons for conducting this study was to provide guidance to the NMC as to how to price its services. Our findings indicate that if the goal of the NMC is to 
cover its recurrent costs, then the price charged for a visit of any type will vary substantially among the various clinics. This is because "overhead" time varies so much. Thus, in the interest of having an equitable policy, the NMC will need to consider charging lower amounts at the less busy clinics. In addition, the NMC may find that charging prices that cover even the recurrent costs at Langa Langa may prove too high, and thus may want to consider a less ambitious scenario and charge prices that cover only the costs of the time that staff spend with clients. However, if such a policy were followed, then the clinics would find that they were unable to cover a substantial proportion of their recurrent costs. 